\title{
Leadership style and organisational commitment in the mining industry in Mpumalanga
}

\begin{tabular}{|c|c|}
\hline $\begin{array}{l}\text { Authors: } \\
\text { Ereen Mclagg } \\
\text { Adéle Bezuide } \\
\text { Chris T. Botha }\end{array}$ & nhout $^{2}$ \\
\hline $\begin{array}{l}\text { Affiliations: } \\
{ }^{1} \text { Department } \\
\text { Management } \\
\text { Development } \\
\text { University of }\end{array}$ & $\begin{array}{l}\text { f People } \\
\text { and } \\
\text { Tshwane } \\
\text { echnology }\end{array}$ \\
\hline \multicolumn{2}{|c|}{$\begin{array}{l}\text { Department of Human } \\
\text { Resource Management, } \\
\text { University of South Africa }\end{array}$} \\
\hline \multicolumn{2}{|c|}{$\begin{array}{l}\text { Correspondence to: } \\
\text { Adéle Bezuidenhout }\end{array}$} \\
\hline \multicolumn{2}{|c|}{$\begin{array}{l}\text { Email: } \\
\text { bezuia@unisa.ac.za }\end{array}$} \\
\hline \multicolumn{2}{|c|}{$\begin{array}{l}\text { Postal address: } \\
\text { PO Box 392, UNISA 0003, } \\
\text { South Africa }\end{array}$} \\
\hline \multicolumn{2}{|c|}{$\begin{array}{l}\text { Dates: } \\
\text { Received: } 30 \text { June } 2012 \\
\text { Accepted: } 27 \text { June } 2013 \\
\text { Published: } 16 \text { Oct. } 2013\end{array}$} \\
\hline \multicolumn{2}{|c|}{$\begin{array}{l}\text { How to cite this article: } \\
\text { Mclaggan, E., Bezuidenhout, } \\
\text { A., \& Botha, C.T. (2013). } \\
\text { Leadership style and } \\
\text { organisational commitment } \\
\text { in the mining industry in } \\
\text { Mpumalanga. SA Journal } \\
\text { of Human Resource } \\
\text { Management/SA Tydksrif vir } \\
\text { Menslikehulpbronbestuur, } \\
\text { 11(1), Art. \#483, } 9 \text { pages. } \\
\text { http://dx.doi.org/10.4102/ } \\
\text { sajhrm.v11i1.483 }\end{array}$} \\
\hline \multicolumn{2}{|c|}{$\begin{array}{l}\text { Copyright: } \\
\text { (C) 2013. The Authors. } \\
\text { Licensee: AOSIS } \\
\text { OpenJournals. This work } \\
\text { is licensed under the } \\
\text { Creative Commons } \\
\text { Attribution License. }\end{array}$} \\
\hline \multicolumn{2}{|l|}{ Read online: } \\
\hline 口itra & $\begin{array}{l}\text { Scan this QR } \\
\text { code with your } \\
\text { smart phone or } \\
\text { mobile device } \\
\text { to read online. }\end{array}$ \\
\hline
\end{tabular}

Orientation: The mining industry is a notoriously difficult environment in which to achieve positive work outcomes, such as organisational commitment. Therefore it was decided to investigate the association between transformational leadership and organisational commitment at a coal mine in Phola in the Mpumalanga province, a geographical area largely neglected by scientific researchers.

Research purpose: The aim of this study was to determine the relationship between the transformational and transactional leadership styles (as measured by the Multifactor Leadership Questionnaire 5X) and organisational commitment (as measured by the Organisational Commitment Questionnaire) in the coal mining industry at a specific site in Phola.

Motivation for the study: A need was identified for research to be conducted in the coal mining industry in Mpumalanga on a leadership style that enhances organisational commitment. Committed employees represent valuable human capital that should be retained for as long as possible

Research design, approach and method: A quantitative, cross-sectional survey design with random sampling $(n=88)$ was used to collect the necessary data. Both instruments showed acceptable internal consistencies.

Main findings: Statistically significant relationships were found between two variables: organisational commitment (for the purposes of this article, this refers to affective commitment) and leadership styles (transactional and transformational).

Practical/managerial implications: Managers and human resource practitioners will benefit from the knowledge gained by the study. Line managers should practise transformational leadership to improve commitment, engagement and satisfaction among their subordinates.

Contribution/value add: The findings of this research add to the body of existing knowledge on transformational leadership and commitment. Valuable insights have been gained on the appropriate leadership style needed to improve commitment in a demanding and underresearched context, namely the coal mining industry in Phola, Mpumalanga.

\section{Introduction}

\section{Problem statement}

\section{Background and contextualisation of the study}

The South African mining industry faces continuous challenges in terms of increased demand for productivity, labour unrest, skills shortages, loss of scarce technical skills due to emigration and high turnover rates (Van Schalkwyk, Du Toit, Bothma \& Rothmann, 2010). The need for inspired leadership is nowhere more evident than in this dynamic context and increasingly stakeholders, including employees, shareholders, politicians and academics, expect leadership to provide solutions to these organisational problems (Hughes, 2010). In today's fast-paced world, the international pressure on organisations to perform better raises the question of how employees will cope and whether they will stay committed to their organisations. South Africa's coal mining industry is under increasing pressure to produce coal in order to meet the country's rapid increasing need for electricity. The current debate revolves mainly around the question of whether the managers themselves have sufficient motivation and energy to lead and engage supervisors and, in turn, the ordinary mine workers into the 21st century (Rothmann \& Joubert, 2007).

Organisations are social systems in which the various human resources are important contributing factors to effectiveness and efficiency. Moreover, the optimal development and utilisation of individual characteristics and competencies are crucial to enhance effectiveness in the workplace (Jonker \& Joubert, 2009). This has led researchers to emphasise the importance of reviewing the factors that influence individuals' job satisfaction and organisational commitment 
(Lumley, 2010) because organisations are unable to succeed without the efforts and commitment of their staff (Rad \& Yarmohammadian, 2006). Managers who fail to lead and motivate their personnel may contribute to low productivity (Laka-Mathebula, 2004).

Success in an organisation in terms of the attainment of goals and realisation of objectives depends on managers and their leadership style(s). Mokgolo, Mokgolo and Modiba (2012) postulate that transformational leadership is vital to effective management, because the effectiveness of the leader determines the eventual success of the organisation. Transformational leaders are able to inspire followers to change their expectations, perceptions and motivations and to work towards common goals (Judge \& Piccolo, 2004). Hence, by adopting an appropriate leadership style, managers will have a positive effect on job satisfaction, productivity and organisational commitment of supervisors and employees (Rad \& Yarmohammadian, 2006). Organisational commitment in particular has attracted considerable interest as attempts have been made to come to a better understanding of the intensity and stability of an employee's dedication to the organisation (Lumley, 2010).

This article is grounded in the multifactor leadership theory, incorporating the transformational, transactional and laissezfaire leadership styles. For the purpose of this article, the two leadership styles that will be measured and reported on are the transformational and transactional leadership styles. A large portion of contemporary leadership research has focused on the effects of transformational and charismatic leadership on the motivation and performance of followers (Lowe \& Gardner, 2000). Similar research studies in different contexts have documented significant positive correlations between transformational leadership and organisational commitment (Emery \& Baker, 2007; Stander \& Rothmann, 2008). In addition, research indicates that transformational leadership is more effective than transactional leadership in developing leaders and enhancing the loyalty, trust, selfesteem and self-efficacy of followers (Northouse, 2010).

Transformational leaders are proactive; they improve follower awareness of transcendent, collective interests and more importantly they inspire followers to achieve extraordinary goals (Antonakis, Avolio \& Sivasubramaniam, 2003). A transformational leader is someone who inspires followers to transcend their own self-interests for the good of the organisation and who is capable of having an effect on their followers (Avolio, Zhu, Koh \& Bhatia, 2004). In contrast, transactional leadership is an exchange process based on the fulfilment of contractual obligations and is typically represented as setting objectives and monitoring and controlling outcomes (Antonakis et al., 2003). Transactional leadership tends to be transitory in that once a transaction is completed the relationship ends or will be redefined (Lussier \& Achua, 2010).

Organisational commitment is conceptualised in the literature as (1) a strong desire to remain a member of a particular organisation, (2) a willingness to achieve high levels of effort on behalf of the organisation, and (3) a definite belief in, and acceptance of, the values and goals of the organisation (Luthans, 2010). Allen and Meyer (1996) in their seminal theory on organisational commitment distinguish between three organisational commitment sub-dimensions: affective, continuance and normative commitment. A significant number of research studies confirm that different leadership styles play a critical role in organisational commitment (Elloy, 2005; Meyer \& Allen, 1997; Rad \& Yarmohammadian, 2006; Shahzad, Rehman \& Abbas, 2010; Stum, 1999) but, due to production pressures, leadership of people in the mining industry is often ignored. For this article, the focus will be on the affective commitment sub-dimension, as previous research results indicate a correlation between leadership style and affective commitment. Managers and supervisors may lose sight of the fact that they are dependent on their employees, to the detriment of the staff and eventually the mining plant's production figures (Laka-Mathebula, 2004).

\section{Trends from the literature: Leadership style}

In a rapidly changing world, in which the ongoing development of the potential of the workforce is considered a prerequisite for remaining competitive, it is possible that leadership styles may fail to meet the leadership challenges confronting most organisations today (Avolio, 2004). Yukl (2010) argues that leadership reflects the assumption that it involves a process in terms of which intentional influence is exerted over other people to guide, structure and facilitate the activities and relationships in either a group or an organisation. Stack (2010) concludes that leadership does not mean being the best; rather it refers to the ability to bring out the best in others. For the purpose of this study, it was decided to use the multifactor leadership questionnaire (MLQ), -version 5X. It focuses on the transactional and transformational leadership styles, with sub-variants of inspirational motivation, intellectual stimulation, individualised consideration and idealised influence. It also investigates the sub-variants of transactional leadership, which include contingent rewards and management by exception (active) and management by exception (passive).

Transformational leadership may be perceived when a leader and a follower enable each other to advance to a higher level of morale and motivation (Nemanich \& Keller, 2007). Through the strength of their vision and personality, transformational leaders are able to inspire followers to change their expectations, perceptions and motivations and to work towards common goals. Judge and Piccolo (2004) are of the opinion that transformational leadership produces numerous positive outcomes. The evidence suggests that transformational leadership is linked to the outcomes that most organisations, individuals and leaders would value. Mokgolo et al. (2012) found in their study within the South African context that engaging in transformational leadership behaviour is an effective strategy to empower line managers to meet the challenges they face.

Transformational leader induces additional effort by directly increasing the follower's confidence as well as by elevating 
the value of outcomes through expanding the transcendental interests and level of needs of the follower (Bass, 1985). The followers of transformational leaders are more satisfied with their leaders in comparison with laissez-faire leaders and, by extension, with their jobs as a whole. Evidence indicates strong correlations between transformational leadership and extra effort, also referred to as organisational citizenship behaviour, on the part of employees (Judge \& Picollo, 2004). Transformational leaders also possess the ability to motivate their subordinates to commit themselves to performance beyond expectation (Howell \& Avolio, 1992). Bass (1990) maintains that this may occur in the following three main ways: firstly by raising the level of awareness of the objective of the organisation and how it is to be achieved, secondly by encouraging co-workers to place the organisation's objectives above their own personal interests and, lastly, by the leader satisfying and stimulating people's higher-order needs.

Bass and colleagues (Avolio, Bass, Jung \& Berson, 2003; Bass, $1985,1997)$ have identified the following five factors which represent the behavioural components of transformational leadership:

- Idealised influence (attributes): Occurs when followers identify with and emulate those leaders who are trusted and perceived to have an attainable mission and vision.

- Idealised influence (behaviour): Refers to leader behaviour that result in followers identifying with leaders and wanting to emulate them.

- Inspirational motivation: Closely related to idealised influence. It implies that leaders behave in ways that motivate and inspire those around them by providing meaning and challenge as regards their followers' work.

- Intellectual stimulation: Occurs when leaders encourage their followers to be innovative and creative by questioning assumptions, reframing problems and approaching old situations in new ways.

- Individual consideration: Occurs when leaders relate to followers on a one-on-one basis in order to elevate goals and develop skills. Such leaders also consider the individual's developmental and growth needs. Managers who demonstrate individualised consideration often coach, mentor and counsel their subordinates.

Transactional leadership is an exchange process which is based on the fulfilment of contractual obligations; it is typically represented as setting objectives as well as monitoring and controlling outcomes (Antonakis et al., 2003). As a result, it tends to be transitory in that, once a transaction has been completed, the relationship either ends or will be redefined (Lussier \& Achua, 2010). Transactional leadership occurs when one person takes the initiative in making contact with others for the purpose of an exchange of valued things. Both parties acknowledge the power relationships of the other and together they continue to pursue their respective purposes. They are not bound together by a mutually similar purpose (Steward, 2006).

Bass (1985) and Bass and Avolio (2004) describe transactional leadership in terms of the use of contingent rewards and management by exception (both active and passive). They view contingent rewards as the rewards that a leader will bestow on a subordinate once the latter has achieved agreed upon goals, encompassing behaviour that is intended to clarify performance expectations, and will follow in exchange for good performance (Valeria, 2009). Transactional leaders rely on goals and objectives that are set, measured and evaluated by the organisation with transactional leaders monitoring followers to ensure that mistakes are not being made (Lussier \& Achua, 2010). Active management by exception spans behaviours that are intended to prevent potential problems in a proactive way before the problems even arise. Passive management by exception includes being on the alert for deviations from the expected performance norms and standards, and providing feedback to correct any such deviations from the norm (Bass \& Avolio, 2004).

\section{Trends from the literature: Organisational commitment}

Organisational commitment is described as a multifaceted concept encompassing hard work, the involvement in organisational activities as well as the implicit and explicit identification with organisational values; it reflects loyalty of employees and is an ongoing process (Passarelli, 2011). According to Greenberg and Baron (2010), organisational commitment is associated with a high level of willingness both to share and to make sacrifices.

Commitment may be conceptualised in a model comprising three components or approaches: affective, continuance and normative commitment (Allen \& Meyer, 1996). These three approaches of commitment may be described as psychologically different orientations towards the organisation.

Affective commitment refers to an individual's orientation towards the organisation in terms of loyalty, identification and involvement (Robbins, Judge, Odendaal \& Roodt, 2010). The individuals who are dedicated on an emotional level usually remain with the organisation because they see their employment as harmonious with the goals and values of the organisation (Ferreira, Basson \& Coetzee, 2010).

Continuance commitment describes the investment that the employee makes in the organisation, for example their contributions, organisation-specific skills that may not be transferable, time and effort. The longer people remain in their organisation, the more they have to lose (Ferreira et al., 2010).

Normative commitment is the third dimension of organisational commitment and reflects feelings of obligation to stay with an organisation as a result of pressures from others.

The multidimensionality of organisational commitment reflects its complex nature. The three types of commitment coexist, are not mutually exclusive and it is possible for an employee to develop one or any combination of the three aspects of commitment (Laka-Mathebula, 2004). Morgan (2012) is of the opinion that, from an attachment perspective, it can be said that affective commitment reflects the strength of the relationship, continuance commitment reflects duration 
and normative commitment reflects responsibility. It is argued that people stay in an organisation either because they want to (affective commitment), because they have to (continuance commitment), or because they ought to (normative commitment). Considering the strengths of correlations identified in previous research studies, for the purpose of this article the focus of the analysis will be on the affective commitment sub-dimension.

Organisational commitment is extremely valuable to an organisation; studies highlight that commitment may impact significantly on the successful performance of an organisation (Nehmeh, 2009). It is essential that employees be reassured that their jobs are secure or they will not be prepared to put in more effort to achieve the organisational objectives. Certain determinants of organisational commitment fall outside of the managers' spheres of control, thus providing them with few opportunities to enhance these feelings of commitment. For example, commitment tends to be lower when the economy is such that employment opportunities are plentiful: an abundance of job options will probably lower continuance commitment.

Despite the fact that leaders are not able to control the external economy there are several options available to them with regard to retaining employees (Greenberg, 2009). Commitment may be enhanced by enriching jobs firstly through giving employees more authority (Coe, Zehnder \& Kinlaw 2008; Greenberg 2009), secondly by increasing employee involvement in decision making (Gennard \& Judge, 2005) and thirdly by aligning the interests of the company with those of the employees (Wellin, 2007). Commitment is a force that binds an individual to a course of action or behaviour, a dynamic process of interaction between individuals and their environment, and as employees become more involved in their organisation, the nature of their commitment changes (Liou, 2008).

\section{Integration of leadership style and organisational commitment}

Rad and Yarmohammadian (2006) hypothesise that leadership styles and organisational commitment are highly interrelated, as leaders who practise effective leadership in planning and administering organisational functions will strongly motivate their employees to commit to the organisation. Lee (2005) also maintains that there is a positive association between transformational leadership and organisational commitment: a transformational leader's consideration for their followers' individuality and willingness to coach them will, in effect, create meaningful exchanges (Lee, 2005).

Stander and Rothmann (2008) found that a leader's behaviour impacts positively on employee attitudes towards their jobs; these positive attitudes in turn result in employees' desire to maintain their relationship with the company concerned.

The purpose of this study was to empirically determine if transformational and transactional leadership styles correlate positively with affective commitment. Association between transformational leadership, transactional leadership and organisational commitment is yet to be determined in the coal mining environment. This article will add to existing research on leadership styles and organisational commitment within the mining environment in South Africa. This information will be valuable to human resource practitioners, as well as line managers within the mining sector in South Africa, as it might contribute to finding a solution to the ongoing labour unrest within this complex context.

\section{Method \\ Research approach}

This study employed a quantitative cross-sectional survey design, measuring the respective constructs and reporting on the statistical correlation between them (Maree, 2007; Mouton, 2006).

\section{Research method \\ Population}

At this specific mining plant in Phola the total number of supervisors or managers and employees was 120. The population included workers from all levels, ranging from unskilled to semi-skilled, supervisors and team leaders to management. The lowest level of employees had a level of literacy that was adequate for the valid completion of the questionnaires. It was decided to approach every individual and request them to participate in the research study. According to Cooper and Schindler (2008), this research procedure, where every individual in the target population has an opportunity to participate in the research, is called a census. According to Cooper and Schindler (2008), a census is appropriate when the population is small and when the elements are quite heterogeneous. They postulate that any sample drawn from a relatively small, heterogeneous population may not be representative of the population from which it is drawn. As the total population at this mining site in Phola was only 120 and the population differed in terms of age, gender, education, position in the organisation and ethnicity, it was judged necessary to use a census instead of sampling. It was decided to employ a field worker to strive for maximum participation. Although all employees and supervisors or managers had the opportunity to participate in the census, 32 declined to participate. The total number of completed questionnaires received was $n=88$. The response rate was thus $73 \%$. This was judged an acceptable response rate to continue with the statistical analysis of the data. The descriptive information of the sample is given in Table 1.

As indicated in Table 1, the majority (75\%) of employees were male, as was to be expected in the male-dominated mining environment in South Africa. Most of the employees were not married (67\%). Only 25\% were on supervisory level, whilst $75 \%$ were employees. The majority of employees (57\%) had completed Grade 12; $24 \%$ of employees indicated that they did not finish their secondary education and only $19 \%$ of employees had a post-matric qualification, which included a technical trade certificate, a national diploma or a degree. 
From this information it is evident that the respondents were mostly not 'highly skilled'.

\section{Measuring instruments}

Two measuring instruments were used in the empirical study. The multifactor leadership questionnaire (MLQ) 5X (Bass \& Avolio, 1990) was developed to measure both transactional and transformational leadership behaviour. For the purposes of this research study, permission was obtained from the developers and the right to use the instrument for this study was purchased. Nine sub-scales, including charisma, individualised consideration, inspirational motivation, intellectual stimulation, contingent reward and management by exception (active) and management by exception (passive), are included in order to differentiate leader behaviour further. The MLQ is unique in the sense that it identifies a wide spectrum of leadership behaviour, from charismatic behaviour to avoidance of leadership (laissez-faire leadership) (Ackermann, Schepers, Lessing \& Dannhauser, 2000).

The organisational commitment questionnaire (OCQ) (Meyer, Allen \& Smith, 1993) was used to measure the organisational commitment of employees. Affective, continuance and normative commitment dimensions are measured by this questionnaire. The questionnaire consisted of 18 items. A five-point Likert response scale was used ranging from 1 (strongly disagree) to 5 (strongly agree).

\section{Research procedure}

The management at the mine was approached and permission was obtained to conduct the study. Throughout the study all efforts were made to maintain high ethical standards. Anonymity and confidentiality were protected at all times. Questionnaires were used to gather primary data and a correlational approach was followed in the data analysis. The questionnaires were hand delivered to the participants

TABLE 1: Characteristics of participants.

\begin{tabular}{llcl}
\hline Item & Category & Frequency & \% \\
\hline Gender & Male & 66 & 75 \\
Marital status & Female & 22 & 25 \\
& Married & 29 & 33 \\
Organisational level & Unmarried & 59 & 67 \\
& Employee & 59 & 75 \\
Educational level & Supervisor & 20 & 25 \\
& Secondary & 21 & 24 \\
& Grade 12 & 50 & 57 \\
Language & Tertiary & 17 & 19 \\
& Nguni & 53 & 62 \\
& Sotho & 20 & 23 \\
& Afrikaans & 13 & 15 \\
\hline
\end{tabular}

TABLE 2: Descriptive statistics and Cronbach alpha coefficients of measuring instruments.

\begin{tabular}{lccc}
\hline Construct & Mean & Standard deviation (SD) & Cronbach's alpha \\
\hline Transformational leadership & 2.55 & 0.89 & 0.92 \\
Transactional leadership & 2.07 & 0.91 & 0.70 \\
Affective commitment & 3.64 & 0.67 & 0.68 \\
\hline
\end{tabular}

and they were completed in pen, returned anonymously and collected immediately afterwards. The respondents in this study represented leaders (team leaders, supervisors and managers) and followers (ordinary mine workers).

\section{Results}

Statistical analysis was carried out with the SPSS version 13 program (SPSS, 2005). Descriptive statistics were used to analyse the data. Cronbach alpha coefficients were used to determine the reliability of the measuring instruments (Bass \& Avolio, 2004; Field, 2005). Pearson product-moment correlation coefficients were used to specify the relationships between the variables. Statistical significance was set at a 95\% confidence interval level $(p<0.05)$. The different languages and different educational levels were collapsed to improve statistical significance, as some of the categories had very low levels of representation. Languages were grouped into Nguni, Sotho and Afrikaans groups. The different educational levels were grouped in secondary and tertiary groups. One-way analysis of variance (ANOVA) is used to determine whether there are any significant differences between the means of three or more independent (unrelated) groups (Field, 2005). In this study, ANOVAs were used to test the correlation between language and organisational commitment. The independent $t$-test is an inferential statistical test that determines whether there is a statistically significant difference between the means in two unrelated groups (Field, 2005). This study employed an independent $t$-test to determine a possible correlation between organisational commitment and gender, marital status, educational level and organisational level.

The descriptive statistics and Cronbach alpha coefficients of the measuring instruments are reported in Table 2. A Cronbach's alpha of $\geq 0.80$ is appropriate for cognitive tests, $\geq 0.70$ is more suitable for ability tests and, for psychological constructs, values below $<0.70$ can realistically be expected (Field, 2005; Pallant, 2011). These results indicate the reliability of the instruments, which is consistent with findings of other research. Due to the low Cronbach alpha of normative and continuance commitment, this sub-dimension was not considered in further analysis.

Table 2 indicates that, numerically, the respondents perceived the leadership style used at this specific plant as more transformational $(M=2.55 ; \mathrm{SD}=0.89)$, although transactional leadership is also present in the way the leadership in this organisation behaves $(M=2.07 ; \mathrm{SD}=0.91)$. Table 2 also shows that respondents seem to be more committed to the organisation in terms of affective commitment $(M=3.64$; $\mathrm{SD}=0.67)$.

An independent sample $t$-test was conducted to test the association between educational level and the affective organisational commitment sub-scale. The results of the $t$-test showed no significant difference in the mean scores for secondary education $(M=3.65$; $\mathrm{SD}=0.643)$ and tertiary education $(M=3.62$; $\mathrm{SD}=0.778)$ in terms of affective commitment: $t(86)=0.168, p=0.867)$. There was also no 
significant difference in mean scores for married employees as regards affective commitment $(M=3.839 ; \mathrm{SD}=0.606)$ compared with those employees who are not married $(M=3.535 ; \mathrm{SD}=0.676): t(78)=1.989, p=0.050$. Accordingly, the empirical study reveals that marital status has no effect on any of the organisational commitment dimensions.

A statistically significant difference did not present in the mean scores for male employees as regards affective commitment $(M=3.625$; $\mathrm{SD}=0.730)$ compared with female employees $(M=3.689$; $\mathrm{SD}=0.474): t(86)=0.384, p=0.702$. Accordingly, the empirical results of this study appear to indicate that neither gender nor educational level nor home language shows any association with affective commitment.

Correlations between the respondents' leadership style and affective commitment levels are reported in Table 3. Positive practical correlation coefficients of medium effect were found between affective commitment and idealised influence (attributes), idealised influence (behaviour), inspirational motivation, intellectual stimulation and contingent rewards. Furthermore, a positive practical correlation coefficient of small effect was found between affective commitment and individual consideration.

This implies a correlation between the transformational and transactional leadership styles used by the supervisor or manager and the level of affective commitment of employees at this coal mining site in Phola in the Mpumalanga province of South Africa.

\section{Discussion}

The objective of this study was to investigate the relationship between leadership styles and organisational commitment at a mining site in Phola in the Mpumalanga province. The results showed that a statistically significant relationship exists between transformational and transactional leadership styles and affective commitment. The results indicated that the subordinates of supervisors who adopt a transformational leadership style, who show an interest in and value their subordinates and make the employees feel important, will show more affective commitment towards their organisation.

TABLE 3: Pearson product-moment correlation as regards organisational commitment and the multifactor leadership questionnaire dimension.

\begin{tabular}{lcc}
\hline Construct & \multicolumn{2}{c}{ Affective commitment (AC) } \\
\cline { 2 - 3 } & Pearson correlation & Significance (2-tailed) \\
\hline Affective commitment & 1.000 & 0.000 \\
Idealised influence (att) & $0.338^{* *} \dagger$ & 0.001 \\
Idealised influence (beh) & $0.493^{* *} \dagger$ & 0.000 \\
Inspirational motivation & $0.397^{* *} \dagger$ & 0.000 \\
Intellectual stimulation & $0.486^{* *} \dagger$ & 0.000 \\
Individualised consideration & $0.289^{* *} \dagger$ & 0.006 \\
Contingent reward & $0.380^{* *} \dagger$ & 0.000 \\
Management by exception (act) & 0.197 & 0.066 \\
Management by exception (pas) & -0.208 & 0.052 \\
\hline
\end{tabular}

att, attributes; beh, behaviour; act, active; pas, passive.

$* *$ Correlation is significant at the 0.01 level ( 2 -tailed).

*, Correlation is significant at the 0.05 level (2-tailed).

$\dagger$, Correlation is practically significant $r \geq 0.30$ (medium effect)

$\$$, Correlation is practically significant $r \geq 0.10$ (small effect).

$n=88$
Such employees will then perceive that they are an important asset of the organisation and this, in turn, will increase their commitment to the organisation. They are expected to show a willingness to stay with the organisation. In addition, they will also feel that their efforts are being recognised. This, in turn, may trigger a chain reaction of the employees working more productively because they know that their hard work will pay off.

This study found that the respondents tend to perceive the leadership style at this coal mining site in Phola, Mpumalanga, to be more transformational and transactional. This finding is in keeping with the findings of Walumbwa, Lawler, Avolio and Wang (2005) and Marmaya, Hitam, Torsiman and Balakrisham (2011, p. 1586). In addition, the respondents perceived that both transformational and transactional leadership may be a result of the augmentation effect, namely the degree to which transformational leadership builds on transactional leadership (Bass, 1999, p. 5; Judge \& Piccolo, 2004, p. 765). Bass (1999, p. 21) comments that the best leaders are both transformational and transactional. These findings will be of value to human resource managers, as line managers will have to be developed and trained in the competencies required by transactional and transformational leadership styles.

Berson and Avolio (2004, p. 641) maintain that transformational leaders perceive the strategic goals of the organisation. They argue that transformational leaders are more sensitive to their environment and thus formulate and disseminate strategic goals that capture both the attention and the interest of their followers. On one hand, managers who have a transformational leadership style will focus on the big picture of the organisation and try to encourage the employees to have the same mindset. On the other hand, transactional leaders are those who guide or motivate their followers in the direction of established goals by clarifying role and task requirements (Robbins, 2003, p. 343). Northouse (2010) further states that transactional leaders place greater emphasis on work standards, assignments and task-oriented goals compared with transformational leaders. Managers with a transactional leadership style would want to be more incentive driven to motivate their employees. As human resource managers are well educated in terms of organisational behaviour, as compared with many technical line managers in a mining context, it is important that these findings be unpacked and that the line managers are informed and guided in terms of their own leadership styles. They should be made aware of how their actions are perceived and how they should communicate the strategic alignment between the organisation's goals and, for example, the productivity targets for their own business units. The human resource manager has to disseminate information on the impact of the specific leadership style on organisational commitment and provide support to the line managers in terms of coaching and mentoring when needed.

The findings of this study indicate an association between the occurrence of transformational and transactional leadership 
and affective commitment. Transformational leaders are able to inspire and motivate their followers to change their expectations. Accordingly, followers at this mining site who are guided by a transformational leader can be expected to be more committed. Committed employees tend to be more willing to accept responsibility than employees who are not committed. Furthermore, employees who have more responsibility tend to feel that the organisation values their services. This, in turn, will improve organisational commitment.

Transactional leaders focus on rewards for the fulfilment of duties. A willingness to expend extra effort indicates some degree of organisational commitment. Extra effort in the mining industry as a result of higher levels of commitment will increase productivity and this, in turn, will increase the organisation's profit.

The affective commitment indicates a moderately positive correlation with idealised influence (attributes), idealised influence (behaviour), inspirational motivation, intellectual stimulation and contingent reward, but a small significant positive correlation only with individualised consideration. Idealised influence (attributes) refers to followers identifying with and imitating their leaders; idealised their influence (behavioural) refers to leader behaviour that results in followers identifying with such leaders. Inspirational motivation implies that leaders behave in ways that motivate and inspire others, whilst intellectual stimulation occurs when leaders encourage their followers to be both innovative and creative. Individualised consideration occurs when leaders relate to followers on a one-on-one basis in order to elevate goals and develop skills. Employees feel more emotionally attached to and involved in the organisation if steps are taken to ensure that they perceive that their work affects the organisation. This is in keeping with the findings of Riaz, Akram and Ijaz (2010).

As regards affective commitment, this study suggests that transformational leadership behaviours are positively related to the way employees feel about wanting to stay with the company. However, a study conducted by Chandna and Krishnan (2009, p. 8) found that affective commitment bore no relation to transformational leadership. Nevertheless, in this study affective commitment shows a significant relationship with one of the transactional leadership subscales, namely contingent reward. Contingent rewards support the reinforcement theory of motivation (Spector, 2008) and this, in itself, will engender a desire to remain with the organisation (Lumley, Coetzee, Tladinyane \& Ferreira, 2011). Employees feel that their efforts are being valued when they are rewarded for what they do. In addition, employees experience a sense of achievement when the supervisors acknowledge their hard work and this, in turn, will then increase the employees' commitment to the organisation and they will work harder and be more productive so as to receive more acknowledgment.

The transformational leadership style consists of the following sub-scales: idealised influence (attributes), idealised influence (behaviour), inspirational motivation, intellectual stimulation and individualised consideration. The results of this study indicate that the employees of supervisors adopting a transformational leadership style will show greater affective commitment towards their organisations as compared with followers of transactional leaders. This finding is in accordance with the findings of Walumbwa et al. (2005), Gao and Bai (2011, p. 46) and Marmaya et al. (2011, p. 1586).

The transactional leadership style consists of the following sub-scales: contingent reward, management by exception (active) and management by exception (passive). It is clear that from this study that contingent reward has a positive correlation with affective commitment. This correlation suggests that leadership behaviours involving the exchange of rewards for realising agreed upon objectives may be related to the way employees feel about having to remain with an organisation. This result also provides an indication that the more passive a leader is in making decisions or providing feedback the less committed an employee will feel to the organisation.

The followers of transformational leaders exhibit higher levels of commitment to their organisational mission, a willingness to work harder, greater levels of trust in their leader and higher levels of cohesion in comparison with followers of laissez-faire leaders (Avolio, 2004). Nyengane (2007) also suggests that if employees feel a sense of belonging to the organisation they will remain with the organisation simply because they want to; in so doing, they exhibit affective commitment.

In view of the fact that the transformational leadership has a relationship with organisational commitment, organisations should attempt to foster this leadership style. By implementing programmes that encourage leaders to develop a transformational leadership style, organisations will be able to improve the commitment levels of their employees (Nyengane, 2007, p. 100). This is an important implication for human resource managers, as they will have to accept responsibility for designing and delivering effective training and development programmes to empower and provide line managers with the necessary knowledge, skills and attitudes to fulfil their mandate in the mining industry. It is also necessary that human resource management and development managers design and implement coaching and mentoring programmes to support line managers after completion of the training courses to allow them to practise and internalise the new behaviours and skills.

A transformational leader should act as a coach, role model and inspirational figure to their subordinates and thus create conditions under which employees contribute enthusiastically to the organisation ( $\mathrm{Nel}$ et al., 2008, p. 365). Managers in the mining industry may become transformational leaders by helping their employees both to understand and to deal with changes in the workplace. In addition, managers should communicate the vision of the organisation to the employees and provide a systematic plan in terms of which this vision may be realised. It is important that managers recognise 
good performance and give credit where it is due. It is also essential that managers provide guidance to employees when the employees are either struggling or making mistakes. Such behaviours prove to employees that the management team both trusts and respects them.

Organisations that require their employees to develop organisational commitment should provide a supportive work environment which, in turn, will create a mutually beneficial environment for both parties. It would appear that both transformational and transactional leadership behaviours have an influence on affective commitment. According to Bass $(1999$, p. 5), the integration of these two leadership styles will have an interactive effect. Managers and supervisors at the research site may increase the level of commitment of the employees by undergoing training on coaching and mentoring practices within the organisation. In addition, managers and supervisors should endeavour to enhance their knowledge of both transformational and transactional leadership paradigms. It is strongly recommended that pay practices and bonus schemes are regularly revised to demonstrate to employees that they are valuable to the leaders in the mining company.

Organisations that require their employees to develop organisational commitment should provide comprehensive training that will encourage leaders to exhibit leadership behaviours such as building trust, inspiring a shared vision, encouraging creativity and recognising accomplishments (Nyengane, 2007, p. 101). Walumbwa and Lawler (2003, p. 1097) are of the opinion that managers and supervisors who are equipped with transformational leadership techniques are likely to engage employees by identifying their strengths, formulating accurate and reasonable expectations for them, developing them and motivating them to perform beyond their expectations.

\section{Limitations of the study}

The findings of the study should be viewed within the context of certain limitations. Firstly, the fact that only one mining site was targeted in this research study, makes it impossible to generalise the results. A diversity of mining sites and equal representation of races, organisational levels and gender should improve the value of the research. Secondly, the selfreport questionnaire that was used limited the respondents to the specific questions asked. Thirdly, some participants may have been concerned about the confidentiality of the survey and chose to answer in what they perceived as an appropriate way. The fact that a cross-sectional design was used can also be viewed as a limitation, as longitudinal data would have contributed to the depth of the data obtained.

\section{Recommendations for future research}

As far as the sample is concerned, replication (with possible enlargement of the sample) of the study on more than one mining site would be highly desirable. In addition, an attempt should also be made to determine the overall commitment of management.

\section{Conclusion}

Organisations should attempt to find tools with which to infuse the desired leadership style and also provide relevant training which is conducive to the development of organisational commitment. Bordin, Bartman and Casimir (2007) mention that supervisors should be empathetic listeners be communicative and sensitive to the needs of subordinates, understanding and approachable. The proposed transformational leadership behaviours will encourage employees to be more committed to their organisation and strive to become exemplary leaders themselves within the organisation in the near future.

\section{Acknowledgements Competing interests}

The authors declare that they have no financial or personal relationship(s) that may have inappropriately influenced them in writing this article.

\section{Authors' contributions}

E.M. (Tshwane University of Technology) initiated the project as part of her M Tech HRM degree. A.B. (University of South Africa) acted as supervisor, and was therefore involved from the conceptualisation of the project, and C.T.B. (Tshwane University of Technology) acted as co-supervisor. The authors wrote the article jointly as a team effort.

\section{References}

Ackermann, C.P., Schepers, J.M., Lessing, B.C., \& Danhauser Z (2000). Die faktorstruktuur van Bass se Veelfaktor-Leierskapvraelys in die Suid-Afrikaanse konteks [The factor structure of Bass's Multifactor Leadership Questionnaire in the South African context]. Journal of Industrial Psychology, 26(2), 58-65.

Allen, N.J., \& Meyer, J.P. (1990). The measurement and variables associated with affective, continuance and normative commitment to the organisation. Journal of Occupational Psychology, 63, 1-18. http://dx.doi.org/10.1111/j.2044-8325.1990. tb00506.x

Allen, N.J., \& Meyer, J.P. (1996). Affective, continuance and normative to the organisation: An examination of the construct validity. Journal of Vocational Behaviour, 49 252-276. http://dx.doi.org/10.1006/jvbe.1996.0043

Antonakis, J., Avolio, B.J., \& Sivasubramaniam, N. (2003). Context and leadership: An examination of the nine-factor full-range leadership theory using the Multifactor Leadership Questionnaire. The Leadership Quarterly, 14(3), 261-295. http://dx.doi. org/10.1016/S1048-9843(03)00030-4

Avolio, B.J. (2004). Leadership development in balance: Made/born. Hillsdale, NJ: Erlbaum.

Avolio, B.J., Bass, B.M., Jung, D.I., \& Berson, Y. (2003). Predicting unit performance by assessing transformational and transactional leadership. Journal of Applied Psychology, 88(2), 207-218. http://dx.doi.org/10.1037/0021-9010.88.2.207, PMid:12731705

Avolio, B.J., Zhu, W., Koh, W., \& Bhatia, P. (2004). Transformational leadership and organisational commitment: Mediating role of psychological empowerment and moderating role of structural distance. Journal of Organisational Behavior, 25, 951-968. http://dx.doi.org/10.1002/job.283

Bass, B.M. (1985). Leadership: Good, better, best. Organisational Dynamics, 13(3), 26-40. http://dx.doi.org/10.1016/0090-2616(85)90028-2

Bass, B.M. (1990). From transactional to transformational leadership: Learning to share the vision. Organisational Dynamics, 18(3), 19-31. http://dx.doi.org/10.1016/00902616(90)90061-S

Bass, B.M. (1997). Does the transactional-transformational leadership paradigm transcend organisational and national boundaries? Journal of American Psychologist, 52(2), 130-139. http://dx.doi.org/10.1037/0003-066X.52.2.130

Bass, B.M. (1999). Two decades of research and development in transformational leadership. European Journal of Work and Organisational Psychology, 8(1), 9-32. http://dx.doi.org/10.1080/135943299398410

Bass, B.M., \& Avolio, B.J. (1990). Developing transformational leadership: 1992 and beyond. Journal of European Industrial Training, 14(5), 21-27. http://dx.doi.org/ 10.1108/03090599010135122

Bass, B.M., \& Avolio B.J. (2004). MLQ multifactor questionnaire. 3rd Sampler set: Technical Report, Leader form, Rater form and Scoring key for MLQ form 5X-short. Mindgarden. 
Berson, Y., \& Avolio, B.J. (2004). Transformational leadership and the dissemination of organisational goals: A case study of a telecommunications firm. The Leadership organisational goals: A case study of a telecommunications firm. The Leadersh
Quarterly, 15(5), 625-646. http://dx.doi.org/10.1016/j.leaqua.2004.07.003

Bordin, C., Bartman, T., \& Casimir, G. (2007). The antecedents and consequences of psychological empowerment amongst Singaporean IT employees. Management Research News, 30(1), 34-46. http://dx.doi.org/10.1108/01409170710724287

Chandna, P., \& Krishnan, V.R. (2009). Organisational commitment of information technology professionals: Role of transformational leadership and work-related beliefs. Tecnia Journal of Management Studies, 4(1), 1-13.

Coe, C., Zehnder, A., \& Kinlaw, D.C. (2008). Coaching for commitment: Achieving superior performance from Individuals and teams. San Francisco, CA: Pfeiffer.

Cooper, D.R., \& Shindler, P.S. (2006). Business research methods. Boston, MA: McGraw-Hill.

Elloy, D.F. (2005). The influence of super-leader behavior on organisational commitment, job satisfaction and organisational self-esteem in a self-managed work team. Leadership and Organisational Development Journal, 26(2), 120-127. http://dx.doi. Leadership and Organisational Develop
org/10.1108/01437730510582554

Emery, C.R., \& Barker, K.J. (2007). The effect of transactional and transformational leadership styles on the organizational commitment and job satisfaction of customer contact personnel. Journal of Organizational Culture, Communication and Conflict, 11(1), 77.

Ferreira, N., Basson, J., \& Coetzee, M. (2010). Psychological career resources in relation to organisational commitment: An exploratory study. South African Journal of Human Resource Management, 8(1), 1-10.

Field, A. (2005). Discovering statistics using SPSS. London: Sage.

Gao, F.Y., \& Bai, S. (2011). The effects of transformational leadership on organisational commitment of family employees in Chinese family business. International Conference on Economic Trade and Development, 7, 43-48.

Gennard, J., \& Judge, G. (2005). Employee relations. (4th edn.). London: Broadway.

Greenberg, J. (2009). Managing behavior in organisations. Upper Saddle River, NJ: Prentice-Hall.

Greenberg, J., \& Baron, R.A. (2010). Behavior in organisations. (4th edn.). Needham Heights, MA: Simon \& Schuster.

Hughes, M. (2010). Managing change: A critical perspective. London: CIPD.

Howell, J.M., \& Avolio, B.J. (1992). The ethics of charismatic leadership: Submission or liberation. Academy of Management Executive, 6(2), 43-56.

Jonker, C.S., \& Joubert, S. (2009). Emotion work and well-being of client service workers within small and medium-sized enterprises. Management Dynamics, 18(2), 35-48.

Judge, T.A., \& Piccolo, R.F. (2004). Transformational and transactional leadership: A meta-analytic test of their relative validity. Journal of Applied Psychology, 89(5), 755-768. http://dx.doi.org/10.1037/0021-9010.89.5.755, PMid:15506858

Laka-Mathebula, M.R. (2004). Modelling the relationship between organisational commitment, leadership style, human resource management practices and organisational trust. Unpublished PhD thesis, University of Pretoria, Pretoria, South Africa.

Lee, J. (2005). Effects of leadership and leader-member exchange on commitment. Leadership and Organisational Development Journal, 26(8), 655-672. http://dx.doi. org/10.1108/01437730510633728

Liou, S.R. (2008). An analysis of the concept of organisational commitment. Nursing Forum, 43(3), September, 117-125. http://dx.doi.org/10.1111/j.1744-6198.2008. 00103.x, PMid:18715344

Lowe, K.B., \& Gardner, W.L. (2000). Ten years of The Leadership Quarterly contributions and challenges for the future. Leadership Quarterly, 11, 459-514. http://dx.doi. and challenges for the future. Leaders
org/10.1016/S1048-9843(00)00059-X

Lumley, E. (2010). Exploring the relationship between anchors, job satisfaction and organisational commitment. Unpublished master's dissertation, Department of organisational commitment. Unpublished master's dissertation, Departm
Industrial and Organisational Psychology, UNISA, Pretoria, South Africa.

Lumley, E.J., Coetzee, M., Tladinyane, R., \& Ferreira, N. (2011). Exploring the job satisfaction and organisational commitment of employees in the information technology environment. Southern African Business Review, 15(1), 100-118.

Lussier, R.N., \& Achua, C.F. (2010). Leadership: Theory, application and skill development. (3rd edn.). Mason, $\mathrm{OH}$ : South-Western Cengage Learning.

Luthans, F. (2010). Organizational behavior. (11th edn.). International: McGraw Hill.

Marmaya, N.H., Hitam, M., Torsiman, M., \& Balakrisham, B.K.P.D. (2011). Employees' perception of Malaysian managers' leadership styles and organisational commitment. African Journal of Business Management, 5(5), 1584-1588.

Maree, K. 2007. First steps in research. Pretoria: Van Schaik.

Meyer, J.P., \& Allen, N.J. (1997). Commitment in the workplace: Theory, research and application. London: Sage.

Meyer, J.P., Allen, N.J., \& Smith, A. (1993). Commitment to organisations and occupations: Extension and test of a three-component conceptualisation. Journal of Applied Psychology, 78, 538-555. http://dx.doi.org/10.1037/0021-9010.78.4.538
Mokgolo, M.M., Mokgolo, P., \& Modiba, M. 2012. Transformational leadership in the South African public service after the April 2009 national elections. South African Journal of Human Resource Management/Suid-Afrikaanse Tydskrif vir Menslikehulpbronbestuur, 10(1), Art. \#334, 9 pages. http://dx.doi.org/10.4102/ sajhrm.v10i1.334

Morgan, S.J. (2012). The human side of outsourcing: Psychological theory and management practice. West Sussex: John Wiley.

Mouton, J. (2006). Understanding social research. Pretoria: Van Schaik.

Nehmeh, R. (2009). What is organisational commitment, why should managers want it in their workforce and is there any cost effective way to secure it? SMC Working Paper, 5, 1-9.

Nel, P.S., Werner, A., Haasbroek, G.D., Poisat, P., Sono, T., \& Schultz, H.B. (2008). Human resource management. (7th Edn.). South Africa: Oxford.

Nemanich, L.A., \& Keller, R.T. (2007). Transformational leadership in an acquisition. A field of study of employees. Leadership Quarterly, 18, 49-68. http://dx.doi.org/ 10.1016/j.leaqua.2006.11.003

Northouse, P.G. (2010). Leadership: Theory and practice. California: Sage. PMCid:PMC2946584

Nyengane, M.H. (2007). The relationship between leadership style and employee commitment: An exploratory study in an electricity utility of South Africa. Unpublished MBA dissertation, Rhodes University, Grahamstown, South Africa.

Pallant, J. (2011). SPSS survival manual. New York: McGraw Hill.

Passarelli, G. (2011). Employees' skills and organisational commitment. International Business Research, 4(1), 28-42.

Rad, A.M.M., \& Yarmohammadian, M.H. (2006). A study of relationship between managers' leadership style and employees' job satisfaction. Leadership in Health Services, 19(2), xi-xxviii. http://dx.doi.org/10.1108/13660750610665008

Riaz, T., Akram, M.U., \& ljaz, H. (2010). Impact of transformational leadership style on affective employees' commitment: An empirical study of banking sector in Islamabad (Pakistan). Journal of Commerce, 3(1), 43-51.

Robbins, S.P. (2003). Organisational behaviour. (10th edn.). Upper Saddle River, NJ: Prentice Hall.

Robbins, S.P., Judge, T.A., Odendaal, A., \& Roodt, G. (2010). Organisational behaviour Global and South African perspective. (2nd edn.). Cape Town: Pearson Education.

Rothmann, S., \& Joubert, J.H.M. (2007). Job demands, job resource, burnout and work engagement of managers at a platinum mine in the North West Province. South African Journal of Business Management, 38(3), 49-61.

Shahzad, K., Rehma, K.U., \& Abbas, M. (2010). HR practices and leadership styles as predictors of employee attitude and behaviour: Evidence from Pakistan. European Journal of Social Science, 14(3), 417-426.

Spector, P. (2008). Industrial and organisational behaviour. (5th edn.). Hoboken, NJ: John Wiley.

SPSS Inc. (2005). SPSS 13.0 for Windows. Chicago: Author

Stack, L. (2010). Super competent: The six keys to perform at your productive best. Hoboken, NJ: John Wiley.

Stander, M.W., \& Rothmann, S. (2008). The relationship between leadership, job satisfaction and organisational commitment. South African Journal of Human satisfaction and organisa
Resources, 6(3), 7-13.

Steward, J. (2006). Transformational leadership: An evolving concept examined through the works of Burns, Avolio, and Leithwood. Canadian Journal of Education Administration and Policy, 54, June, 1-29.

Stum, D.L. (1999). Maslow revisited: Building the employee commitment pyramidst. Strategy and Leadership, 29(4), 4-9. http://dx.doi.org/10.1108/10878570110400053

Van Schalkwyk, S., Du Toit, D.H., Bothma, A.S., \& Rothmann, S. (2010). Job insecurity, leadership empowerment behaviour, employee engagement and intention to leave in a petrochemical laboratory. SA Journal of Human Resource Management/ SA Tydskrif vir Menslikehulpbronbestuur, 8(1), Art. \#234, 7 pages. http://dx.doi. org/10.4102/sajhrm.v8il.234

Valeria, A.M. (2009). Developing woman leaders: A guide for men and women in organisations. West Sussex: Wiley \& Blackwell. http://dx.doi.org/10.1002/ 9781444315967

Walumba, F.O., \& Lawler, J.J. (2003). Building effective organisations: Transformation leadership, collectivist orientation, work-related attitudes, and withdrawal behaviours in three emerging economies. International Journal of Human Resource Management, in three emerging economies. International Journal of Human Resource
$14,1083-1101$. http://dx.doi.org/10.1080/0958519032000114219

Walumbwa, F.O., Lawler, J.J., Avolio, B.J., \& Wang, P.S.K. (2005). Transformational leadership and work-related attitudes: The moderating effects of collective and self-efficacy across cultures. Journal of Leadership and Organisational Studies, 11(3), 2-16. http://dx.doi.org/10.1177/107179190501100301

Wellin, M. (2007). Managing the psychological contract: Using the personal deal to increase business performance. Hampshire: Gower House. PMid:18032184

Yukl, G. (2010). Leadership in organisations. (7th edn.). Upper Saddle River, NJ: Prentice Hall. 